\title{
Spatiotemporal Correlations Between Water Quality And Microbial Community of Typical Inflow River Into Taihu Lake, China
}

\section{Yajie Zhang}

Zhejiang University

\section{Ye Zhang}

Zhejiang University

\section{Lecheng Wei}

Zhejiang University

Mengyan Li

New Jersey Institute of Technology

Weitang Zhu

Environmental Protection Bureau of Changxing County

Liang Zhu ( $\square$ lilithzhuliang@163.com )

Zhejiang University

\section{Research Article}

Keywords: Taihu Lake, Changxing River, Water quality characteristics, Microbial community, Spatialtemporal distribution

Posted Date: October 28th, 2021

DOI: https://doi.org/10.21203/rs.3.rs-1000115/v1

License: (9) This work is licensed under a Creative Commons Attribution 4.0 International License. Read Full License 


\section{Abstract}

Changxing River, which is a typical inflow river into the Taihu Lake and occurs severe algae invasion, is selected to study the effect of different pollution sources on the water quality and ecological system. Four types of pollution sources, including the estuary of Taihu Lake, discharge outlets of urban wastewater treatment plants, storm water outlets, and non-point source agricultural drainage areas are chosen, and next-generation sequencing and multi-variate statistical analyses are used to characterize the microbial communities and reveal their relationship with water physicochemical properties. Results showed that ammonia nitrogen $\left(\mathrm{NH}_{4}{ }^{+}-\mathrm{N}\right)$, total nitrogen (TN), and total phosphorus (TP) are the main pollutant in Changxing River, especially at storm water outlets. At the same time, the diversity of microbial communities was the highest in the summer, and dominant phyla included Proteobacteria $(40.9 \%)$, Bacteroidetes (21.0\%) and Euryarchaeota (6.1\%) under the condition of algal bloom. Water temperature $(T)$, air pressure $(P)$, concentrations of TP and $C O D_{M n}$ were the important variables for the succession of microbial community. From the perspective of different pollution types, relative abundances of Microcystis and Nostocaceae at the estuary of Taihu Lake were correlated positively with dissolved oxygen (DO) and pH, and Pseudomonas and Arcobacterwere correlated positively with concentrations of $\mathrm{TN}$ and nitrate nitrogen $\left(\mathrm{NO}_{3}{ }^{-} \mathrm{N}\right)$ at storm water outlets. The results provide a reference for the impact of pollution types on river microbial ecosystem under complex hydrological condition and a guidance for the selection of restoration techniques for polluted rivers entering an important lake.

\section{Introduction}

Over the past decades, rapid industrialization and urbanization around the Taihu Lake Basin in China have caused severe water pollution issues, attracting the considerable attention (Yang et al., 2013; Zhang et al., 2019c). According to the Health Status Report of Taihu Lake in 2018, the average comprehensive trophic level index (TLI) was 60.3, indicating moderate eutrophication (The higher the index value, the more nutritious it is). The annual total nitrogen in the most polluted area in Taihu Lake was above 2.0 $\mathrm{mg} / \mathrm{L}$, and the average concentration of chlorophyll a was $31.5 \mathrm{mg} / \mathrm{m}^{3}$. The input and retention of highload pollutants have caused the eutrophication and frequent algae outbreaks in Taihu Lake.

Based on the statistics of Taihu Lake Basin and Southeast Rivers Water Resources Bulletin in 2018, 10 of 22 major inflow rivers around the Taihu Lake were contaminated, with COD above $20 \mathrm{mg} / \mathrm{L}$ and TN above 1.0 mg/L. Previous studies (Wang et al., 2007; Rodriguez-Mozaz et al., 2015; Zhou et al., 2016a; Du et al., 2017; Zhang et al., 2019c) showed that inflow rivers were the main sources that contribute to eutrophication, algae blooms, and water quality deterioration in downstream receiving lakes (reservoirs), especially for Taihu Lake. Wang et al. (2011) calculated that more than $90 \%$ of the total nutrient load of COD, ammonia nitrogen, total nitrogen, and total phosphorus in Taihu Lake were attributed to the rivers in the Changxing County and Huzhou Urban Area. The highest concentration of $\mathrm{NO}_{3}{ }^{-} \mathrm{N}$ in Changxing River reached $14 \mathrm{mg} / \mathrm{L}$ (Yang et al., 2013). Since the water diversion from Yangtze River to Taihu Lake was implemented in 2002, the water level of Taihu Lake has risen each year, which is worsened by the over- 
exploitation and utilization of water resources and meteorological factors, such as precipitation, wind velocity, and wind direction (Liu et al., 2013). Frequent backwatering of the lake and serious accumulation of cyanobacterial blooms in the river flowing into the lake also weaken the natural restoration. Over the past years, water quality of the section of Changxing River remain unstable without meeting the environmental quality standard for surface water in China. Therefore, the development of efficient polluted river restoration technology is needed to prevent and control eutrophication of Taihu Lake.

Microorganisms exist in river ecosystems either in the suspended phase or attached to biofilms (Battin et al., 2016). The composition and structure of microorganisms in river ecosystems are highly dynamic. They can reflect different ecological functions and show a high degree of sensitivity to changes of environmental condition (Lundgard et al., 2017), and are recognized as one of the important indicators for the stability of aquatic ecosystems (Liao et al., 2018; Sharuddin et al., 2018; Santos et al., 2019). A number of studies noted that the effect of seasons on microbial community in rivers were greater than locations (Zhang et al., 2019a, b; Zhu et al., 2019). Microbial community changes generally follow a pattern of periodic recurrence and exhibit a predictable temporal pattern in a single habitat (Gilbert et al., 2012; Portillo et al., 2012). Zhang et al. (2012) found that there was a significant difference in microbial community compositions between samples collected in the lower temperature months (December to February of the following year) and the higher temperature months (June to October) $(R=0.102, p<$ 0.005). Further, the relative abundance of cyanobacteria in Fast River during the rainy season was about 10 times higher than that in dry season, and the abundance of actinomycetes in the dry season was much higher than that in rainy season by contrast (Sun et al., 2017). However, other studies have found that the differences in the spatial pattern of microbial communities may be greater than the seasonal differences (Ouyang et al., 2020). For instance, a significant positive correlation was reported between the Gammaproteobacteria and TN in Chaohu Lake, China, which suggested their roles in nitrogen transformation and cycling in aquatic ecosystems (Zhang et al., 2020). However, studies have also shown that small phytoplankton with low nutrient requirements for nitrogen and phosphorus could become dominant algal species in oligotrophic waters (Jiang et al., 2015).

Therefore, correlating physiochemical characteristics with changes in the microbial communities provides hypotheses as to the ecological function of rivers and likely successful remediation strategies. In this study, Changxing River was selected as a major inflow river located at South Taihu Lake Basin. We collected four types of impacted sites, including the estuary of Taihu Lake, discharge outlets of urban wastewater treatment plants, storm water outlets, and non-point source agricultural drainage areas over four seasons. The microbial communities, water physicochemical properties, and their spatiotemporal correlation was investigated. The results provide a reference for the impact of pollution types on river microbial ecosystem under complex hydrological condition and a guidance for the selection of restoration techniques for polluted rivers entering an important lake.

\section{Materials And Methods}

\subsection{Study area and sampling sites}


Changxing River is one of the main inflow rivers in south Taihu Basin. It plays a vital role in water supply, irrigation, tourism and fishery, and is one of the major navigable rivers in Zhejiang Province (Liu et al., 2011; Wu et al., 2018). However, there are many sources of pollution along the river, such as farmland, residences, catering, industry and urban wastewater treatment plants. Continuous discharge of irrigation water, urban sewage, and rainwater runoff is conducive to complex and serious water pollution in Changxing River.

Based on pollution sources along the Changxing River, the pollution types were divided into four categories: the estuary of Taihu Lake (I), discharge outlets of urban wastewater treatment plants (II), storm water outlets (III), and non-point source agricultural drainage areas as (IV). For each type, we selected 2-3 sites for water sample collection in the summer (August 2018), autumn (October 2018), winter (January 2019), and spring (March 2019), respectively. Geographic locations of the sampling sites are described in Table 1 and depicted in Fig. 1.

Table 1

Location of sampling sites along the Changxing River

\begin{tabular}{|c|c|c|c|c|}
\hline \multirow[t]{2}{*}{ Type } & \multirow[t]{2}{*}{ No. } & \multirow[t]{2}{*}{ Name of sites } & \multicolumn{2}{|c|}{ Geographic locations } \\
\hline & & & East longitude & North latitude \\
\hline \multirow[t]{2}{*}{ I } & 1 & XinTang section & 119.992641 & 31.032865 \\
\hline & 2 & Hexixingang & 119.986131 & 31.054735 \\
\hline \multirow[t]{2}{*}{ ॥ } & 3 & Shenchang sewage treatment plant & 119.944546 & 31.007868 \\
\hline & 4 & Xingchang sewage treatment plant & 119.930341 & 31.002718 \\
\hline \multirow[t]{3}{*}{ III } & 5 & Cangqian sluice & 119.911909 & 30.999738 \\
\hline & 6 & FengHuang Community & 119.901406 & 31.000428 \\
\hline & 7 & ShuiMuHuaDu Community & 119.888209 & 30.999821 \\
\hline \multirow[t]{2}{*}{ IV } & 8 & Xizhuang & 119.856806 & 30.986991 \\
\hline & 9 & Changqiao & 119.865614 & 30.984250 \\
\hline
\end{tabular}

Water samples were collected using a plexiglass sampler. At each sampling site, three water samples were taken in $500-\mathrm{mL}$ bottles. After acidification to $\mathrm{pH}<2$ with $\mathrm{H}_{2} \mathrm{SO}_{4}$, samples were stored at $4^{\circ} \mathrm{C}$ prior to physicochemical analysis. $1 \mathrm{~L}$ of surface water at each sampling site was also collected into glass bottles for algae examination by microscopy. Another $1 \mathrm{~L}$ of surface water at each sampling site was sampled and filtered through $0.22-\mu \mathrm{m}$ glass fiber filters $(50 \mathrm{~mm}$ diameter, Shanghai) by vacuum filtration to collect the microorganisms. The filters were immediately stored at $-80^{\circ} \mathrm{C}$ in the laboratory prior to DNA extraction (Liao et al., 2018).

\subsection{Physicochemical analysis methods}


The water temperature $(T)$, air pressure (P), dissolved oxygen (DO), electrical conductivity (EC), total dissolved solids (TDS), salinity (SAL), $\mathrm{pH}$, and oxidation reduction potential (ORP) were measured in situ at each site by using a multi-parameter water quality monitor (YSI Professional Plus, USA). Total Organic Carbon (TOC) and total nitrogen (TN) were measured by TOC analyzer (TOC-VCPH, SHIMADZU). Nessler's reagent spectrophotometry, $\mathrm{N}$-(1-naphthyl) ethylene diamine dihydrochloride spectrophotometric, ultraviolet spectrophotometry and ammonium molybdate spectrophotometric methods were used to determine the concentrations of ammonia nitrogen $\left(\mathrm{NH}_{4}{ }^{+} \mathrm{N}\right)$, nitrate $\left(\mathrm{NO}_{3}{ }^{-} \mathrm{N}\right)$, nitrite $\left(\mathrm{NO}_{2}{ }^{-} \mathrm{N}\right)$, and total phosphorus (TP) in surface water, respectively (State Environmental Protection Administration of China., 2002). All physicochemical parameters were calculated as the average of triplicate measurements.

\subsection{Analysis of microbial community}

The PowerSoil DNA extraction kit (MoBio Laboratories, CA, USA) was used to extract the DNA of microorganisms filtered on water filtration membranes. The V3-V4 region of 16S rRNA was amplified using universal primers 515F (5 '-GTGCCAGCMGCCGCGGTAA -3') and 806R (5 '-

GGACTACHVGGGTWTCTAAT-3') (Liao et al., 2018). All PCR reactions were performed using Phusion® high-fidelity PCR Master Mix (New England Biolabs). The PCR products were then purified using GeneJETTM Gel extraction kit (Thermo Scientific), and finally sequenced using the lon S5TM XL platform.

Sequence analysis was performed by the Uparse software (Version 7.0.1001), which assigned sequences with $\geq 97 \%$ similarity to OTUs for species annotation. Finally, the diversity indexes were estimated using QIIME (Version 1.7.0).

\subsection{Statistical analysis}

Principal Component Analysis (PCA) was analyzed using the IBM SPSS Statistics 20 software to preprocess the data. Spearman's rank correlation after Shapiro-Wilk test was used to analyze the correlation of water quality physicochemical indicators. One-way ANOVA, Kruskal Wallis test, and ANOSIM were used to determine the significance of differences in physicochemical indicators of water quality and relative microbial abundance in different seasons and pollution types with SPSS, GraphPad Prism, and R (Version 3.5.2). Canoco 4.5 redundancy analysis (RDA) was used to determine the relationship between the environment variables and microbial community structures. The ward.D was used to perform clustering analysis (CA) based on the relative abundance of microbial communities. BIOENV correlation analysis was used to study the relationship between microbial community structure and the environment variables in different seasonal and identify the best combination of environmental variables.

\section{Results And Discussion}

\subsection{Spatial and temporal variations of water quality characteristics}


As shown in Fig. 2a, the change trend of the average water temperature $(\mathrm{T})$ in Changxing River was summer $\left(31.3^{\circ} \mathrm{C}\right)>$ autumn $\left(22.6^{\circ} \mathrm{C}\right)>\operatorname{spring}\left(14^{\circ} \mathrm{C}\right)>$ winter $\left(7.6^{\circ} \mathrm{C}\right)$. pH was neutral to slightly alkalescent (7.0-7.9), which may be related to the nature of the upstream soil (Guo, 2017), or affected by the surface runoff of irrigation from farmland (Feng et al., 2017). The concentrations of DO in summer and autumn were $3.98 \mathrm{mg} / \mathrm{L}$ and $3.49 \mathrm{mg} / \mathrm{L}$, respectively. They were both lower than the Class III standard limit ( $\geq 5 \mathrm{mg} / \mathrm{L}$ ) of the surface water environmental quality standard (GB3838-2002), and significantly $(p<0.0001)$ lower than those in winter and spring $(9.50,7.77 \mathrm{mg} / \mathrm{L})$. There was a significant negative correlation between DO and T $(r=-0.790, p<0.01)$, indicating that DO was generally higher in the dry season due to the influence of rainfall and temperature (Shi et al., 2017).

The concentration of TN in autumn was the highest $(4.99 \mathrm{mg} / \mathrm{L})$, followed by spring $(4.50 \mathrm{mg} / \mathrm{L})$, winter $(4.31 \mathrm{mg} / \mathrm{L})$ and summer $(3.22 \mathrm{mg} / \mathrm{L})$. The concentration of $\mathrm{NH}_{4}{ }^{+}-\mathrm{N}$ in autumn was also the highest (1.92 $\mathrm{mg} / \mathrm{L})$. In other seasons, $\mathrm{NH}_{4}{ }^{+}-\mathrm{N}$ concentrations also exceeded the limit of Class III of the environmental quality standard for surface water $(\leq 1 \mathrm{mg} / \mathrm{L}) . \mathrm{NO}_{3}{ }^{-}-\mathrm{N}$ was the main form of inorganic nitrogen in the water body of Changxing River (58\%). The concentrations of $\mathrm{NO}_{3}{ }^{-} \mathrm{N}$ in summer and autumn (1.65 and $1.96 \mathrm{mg} / \mathrm{L}$, respectively) were significantly lower than those in winter and spring (2.74 and $3.06 \mathrm{mg} / \mathrm{L}$, respectively). The concentrations of TP in summer and autumn ( 0.39 and $0.44 \mathrm{mg} / \mathrm{L}$, respectively) were higher than those in winter and spring (0.16 and $0.18 \mathrm{mg} / \mathrm{L}$, respectively).

ANOVA analysis in Fig. 2b found that $\mathrm{T}, \mathrm{P}, \mathrm{pH}, \mathrm{ORP}, \mathrm{NO}_{2}{ }^{-}-\mathrm{N}$, and $\mathrm{NO}_{3}{ }^{-}-\mathrm{N}$ didn't change significantly among the four pollution types $(p>0.05)$. The concentrations of TDS, EC, and SAL in water samples from the discharge outlets of urban wastewater treatment plants (II) were $307 \mathrm{mg} / \mathrm{L}, 422 \mu \mathrm{S} / \mathrm{cm}$ and $0.24 \mathrm{ng} / \mathrm{L}$, respectively, which were all higher than other pollution source types. It was mainly related to the effluent composition of the sewage treatment plant. The concentrations of $\mathrm{TN}, \mathrm{NH}_{4}{ }^{+}-\mathrm{N}, \mathrm{TP}, \mathrm{TOC}$, and $\mathrm{COD}_{\mathrm{Mn}} \mathrm{Were}$ the highest at the monitoring points of the storm water outlets (III), indicating that the pollution of the storm water outlets (III) was relatively serious. The average concentrations of $\mathrm{TN}_{1} \mathrm{NH}_{4}{ }^{+}-\mathrm{N}$, and TP in water samples from the storm water outlets (III) were $5.30,2.19$, and $0.55 \mathrm{mg} / \mathrm{L}$, respectively, which were $1.2-$ 1.7, 2.4-5.2 and 3.0-3.9 times higher than those for other pollution types $(p<0.01)$. According to the statistical analysis, the $\mathrm{NH}_{4}{ }^{+}-\mathrm{N}$ emissions of domestic sewage in Changxing County (597 tons) accounted for $89.6 \%$ of the total $\mathrm{NH}_{4}{ }^{+}-\mathrm{N}$ emissions in 2018 , indicating that the rain sewage discharge at the storm water outlets (III) had an impact on the concentration increase of $\mathrm{TN}, \mathrm{NH}_{4}{ }^{+}-\mathrm{N}$ and TP in Changxing River sections.

In addition, the lowest amount of DO was found at the estuary of Taihu Lake (I) during the autumn cyanobacteria bloom (2.20 mg/L) in Fig. 2c. Simultaneously, comparing with other seasons and pollution types, the concentrations of $\mathrm{NH}_{4}{ }^{+}-\mathrm{N}$ and TP were particularly prominent at the storm water outlets (III) in autumn (3.62 and $0.99 \mathrm{mg} / \mathrm{L}$, respectively). The issue of commingling discharge of rain precipitation and municipal sewage at the storm water outlets (III) in autumn had a particularly significant impact on the nutrient level in Changxing River. 
In general, the average concentrations of $\mathrm{NH}_{4}{ }^{+} \mathrm{N}, \mathrm{TN}$, and TP in Changxing River in autumn were 1.92, 4.99 , and $0.44 \mathrm{mg} / \mathrm{L}$, respectively, which were the highest. The sites with the highest concentrations of nutrient pollution occurred in the storm water outlets (III) with $\mathrm{NH}_{4}{ }^{+}-\mathrm{N}, \mathrm{TN}$, and TP concentrations of 2.19, 5.30 and $0.55 \mathrm{mg} / \mathrm{L}$, respectively.

\subsection{Analysis of microbial community in Changxing river}

The Shannon index characterizes the diversity of microbial community, whereas the Chao 1 index represents the species richness in microbial communities (Ren et al., 2018). The results showed that seasonal variation was the main factor affecting the diversity of microbial community (Fig. 3). The diversity of aquatic microbial communities in summer was the highest, with Shannon and Chao1 indexes of 9.4 and 3,278, respectively. In summer, high temperature can enhance the activity of microorganisms, and surface runoff from precipitation can introduce microorganisms and nutrients from the upstream (Feng et al., 2016), contributing to the highest diversity.

The estuary of Taihu Lake (I) had the highest Shannon index (8.2), while the non-point source agricultural drainage areas (IV) had the lowest Shannon index (7.1). The Chao1 index of the discharge outlets of urban wastewater treatment plants (II) was the highest $(1,974)$, while the Chao1 index of the non-point source agricultural drainage areas (IV) was the lowest (1502). According to the analysis, the geographic location of the estuary of Taihu Lake (I) and the effluent sludge of the urban wastewater treatment plants (II) both affected the diversity of the microbial population of the sewage body (Lu et al., 2016; Tang et al., 2016). In general, the diversity of the microbial community at the monitoring points of different pollution types was not significant. The functional redundancy between microbial groups and the hydraulic distribution of rivers may stabilize microbial diversity against environmental fluctuations (Zeglin, 2015).

Proteobacteria was the dominant phylum across all monitoring sites (accounting for $45.8 \%$ on average), followed by Bacteroidetes (18.9\%), Cyanobacteria (12.8\%), Firmicutes (4.6\%), Actinobacteria (4.0\%), Euryarchaeota (1.7\%), Chloroflexi (1.6\%), Acidobacteria (1.5\%), Verrucomicrobia (1.0\%), and Nitrospirae $(0.9 \%)$. According to the Kruskal-Wallis Test, the dominant phyla in summer included Proteobacteria (40.9\%), Bacteroidetes (21.0\%), Euryarchaeota (6.1\%). Further, the relative abundance of Euryarchaeota $(6.12 \%, \mathrm{p}<0.001)$ and Nitrospirae $(3.13 \%, \mathrm{p}<0.001)$ in summer were significantly higher than other seasons. Analysis of similarities (ANOSIM) revealed significant differences in the relative abundance of dominant microbial community $(R=0.62, p=0.001)$ between different seasons.

Note that the relative abundance of Cyanobacteria was the highest at the non-point source agricultural drainage areas (IV, 32.3\%) (Fig. 4) due to the influence of agricultural non-point source nitrogen pollution load. This phenomenon was especially prominent in autumn. At the estuary of Taihu Lake (I),

Cyanobacteria were highly enriched, in autumn and spring, at the highest of $41.9 \%$ in spring. This was in good agreement with previous studies reporting the highest algae bloom in March at the estuary of Taihu Lake (I) (Hampel et al., 2018). At the same time, the backflow and retention of inflow-rivers are more frequent during normal and dry seasons (i.e., spring). Therefore, Cyanobacteria in Changxing River are 
attributed to the eutrophication of the non-point source agricultural drainage areas in autumn and backflow of algae in Taihu Lake in spring.

However, Proteobacteria was relatively abundant in water samples collected at the discharge outlets of urban wastewater treatment plants (II, 53.8\%) and the storm water outlets (III, 55.2\%), which may be related to their roles in nitrification, denitrification, and other functions.

At the genus level, more taxa showed distinctive differences in their relative abundances among different seasons or pollution types. The heatmap in Fig. 6 showed the genera with the top 80 relative abundances in Changxing River. Dominant genera included Microcystaceae (19.3\%), Flavobacterium (9.6\%), and Pseudomonas (8.9\%).

Microcystis in the genera of Microcystaceae is one of the most dominant cyanobacteria found in the algae blooms at Taihu Lake, which has attracted great attention since it is culprit that secrets highly toxic and persistent microcystin (Shi et al., 2015). The microbial community analysis results showed that the relative abundance of Microcystaceae in spring and autumn (19.8\% and 14.3\%, respectively) was higher than that in summer and winter $(2.4 \%$ and $9.7 \%$, respectively). The two highest relative abundances were observed at the non-point source agricultural drainage areas (IV, 47.7\%) in autumn and the estuary of Taihu Lake $(\mathrm{I}, 41.9 \%)$ in spring. Although Microcystaceae was relatively high in general at the non-point source agricultural drainage areas (IV) due to the input of agricultural non-point source nitrogen load (Paerl et al., 2016), only in the spring, the Microcystis at the estuary of Taihu Lake (I) had the highest relative abundance (41.9\%). Previous investigations have shown March as the month with the heaviest cyanobacterial blooms in Taihu Lake (Hampel et al., 2018). During the dry season or the flat water period, backflow stagnation occurs frequently at the river channels around the lake. This likely explains why the Microcystaceae was highly enriched in the Taihu Lake in the spring. The optimal TN/TP ratio in water to promote algae blooms is between 13-35. When this ratio is below 13 , cyanobacteria bloom can rarely occur. According to our water quality monitoring data, the TN/TP ratio at the estuary of Taihu Lake (I) was 8 in summer, and the other seasonal ratios were between 20 and 35, but there was no cyanobacteria bloom at the estuary of Taihu Lake (I) in winter. It indicated that the relatively high abundance of Microcystis at the estuary of Taihu Lake (I) in spring and autumn was mainly caused by algae backflow.

The relative abundance of Flavobacterium belonging to Bacteroidetes was relatively high in winter $(11.0 \%)$, which may be related to the psychrophilic nature of several species in Flavobacterium (Lopes et al., 2016). In addition, Flavobacterium exhibited the highest relative abundances (15.6\%-19.0\%) at the discharge outlets of urban wastewater treatment plants (II) and the storm water outlets (III). Some Flavobacterium species can participate in denitrification, although this genus also contains fish pathogens(Liu et al., 2017b).

The relative abundances of Pseudomonas in winter and spring (7.5\%-8.3\%) were higher than in summer and autumn (0.5\%-1.6\%). Bacteria belonging to Pseudomonas were highly enriched at the discharge outlets of urban wastewater treatment plants (II, 12.6\%-17.6\%) and the storm water outlets (III, 
$12.0 \%-12.4 \%)$. Pseudomonas contains a diversity of heterotrophic bacteria and some of them are known to perform denitrification at low temperature (Yang et al., 2018b).

In addition to Flavobacterium and Pseudomonas, there were other denitrifying bacteria prevalent in Changxing River Acinetobacter, Rhodobacter, Dechloromonas, Thiobacillus, Hydrogenophaga, Aeromonas, Stenotrophomonas, Zoogloea, Comamonas, etc. (Zhang et al., 2011; Zhou et al., 2016b; Kim et al., 2018; Li et al., 2018b; Martinez-Santos et al., 2018; Zhou et al., 2019) showed high relative abundances in autumn and significant enrichment at the storm water outlets (III). Microorganisms can participate in ammonia oxidation alone (Fitzgerald et al., 2015), such as Sphingomonas and Nitrospirae, showed relatively low abundance $(0.1 \%$ and $0.9 \%)$.

\subsection{Correlation between microbial communities and environmental variables}

Redundancy analysis (RDA) was conducted to evaluate relationships between relative abundances of dominant genera and environmental variables detected in the water samples. As shown in Fig. 7a, T, $\mathrm{COD}_{\mathrm{Mn}}$, DO, $\mathrm{P}$, and $\mathrm{NO}_{2}^{-}-\mathrm{N}$ had a relatively large impact on the seasonal distribution differences of the microbial community in Changxing River. Due to the large number of environmental variables with influence effects, the BIOENV analysis was used to identify the best combination of environmental variables. Therefore, $\mathrm{T}, \mathrm{P}, \mathrm{TP}$, and $\mathrm{COD}_{\mathrm{Mn}}$ were the highest combination and the interpretation quantity of the BIOENV analysis is $78.3 \%$. Although the environmental variables had little influence on the distribution of microbial community in different pollution types in Changxing River. The microbial community structure at the storm water outlets (III) was still significantly affected by TP, T and $C O D_{M n}$ in summer, and affected by $\mathrm{NH}_{4}{ }^{+}-\mathrm{N}$ in autumn (Fig. 7b).

As shown in Fig. 8a, Proteobacteria, Bacteroidetes and Firmicutes were positively correlated with EC, TP, TN, TDS, and SAL. Actinobacteria and Cyanobacteria were positively correlated with $\mathrm{DO}, \mathrm{NO}_{3}{ }^{-}{ }^{-} \mathrm{N}$, and $\mathrm{P}$. Acidobacteria, Euryarchaeota, Chloroflexi, Acidobacteria, Verrucomicrobia and Nitrospirae were positively correlated with $\mathrm{COD}_{\mathrm{Mn}}, \mathrm{T}, \mathrm{ORP}$, and $\mathrm{pH}$.

At Taihu Lake, Microcystis and Nostocaceae were highly abundant and their relative abundances were positively correlated with $\mathrm{pH}$. Previous studies revealed that higher $\mathrm{pH}$ of the water body can promote the growth and reproduction of cyanobacteria (Unrein et al., 2010; Wood et al., 2015). Microcystis was also positively correlated to DO (Fig. 8b). In addition, Microcystis is more competitive for $\mathrm{NH}_{4}{ }^{+} \mathrm{N}$ than most nitrifying bacteria (Paerl et al., 2014; Hampel et al., 2018), and serious accumulation of Microcystis may inhibit the nitrogen cycle of aquatic ecosystems.

\subsection{Suggestion for remediation of Changxing River}

According to the above results, restoration of the estuary of Taihu Lake (I) should focused on addressing the accumulation problem of cyanobacterial blooms caused by the backflow of cyanobacteria from Taihu Lake and strengthening the colonization of nitrifiers and denitrifiers. In the spring, the DO is 
sufficient and the $\mathrm{pH}$ is high. The $\mathrm{pH}$ of the water body can be lowered by increasing the hydraulic circulation in the detention area (Cerco et al., 2013), such as connecting water systems, ecological water replenishment and installing aeration push flow (Lilndenschmidt, 1999). Simultaneously, the cyanobacteria can be removed in situ by arranging enclosures, floating dam interceptions. In the autumn, the DO content is low and the $\mathrm{NH}_{4}{ }^{+}-\mathrm{N}$ content is high due to the eutrophication at the non-point source agricultural drainage areas (IV). Reoxygenation and capping zeolite or clay materials can be used to enhance the colonization of ammonia-oxidizing bacteria (Arnon et al., 2007; Chen et al., 2018). Moreover, the external load into the lake can be reduced by increasing rural sewage treatment and controlling agricultural non-point source pollution. Precise ecological dredging of sediments can also be carried out to effectively reduce the internal load and curb the release of nutrients from sediments.

This study found that the DO content at the storm water outlets (III) was low, especially in summer and autumn. The lowest DO was only $1.7 \mathrm{mg} / \mathrm{L}$, impairing nitrifying bacteria. Current common rainwater restoration technologies include artificial aeration (Tang et al., 2009; He et al., 2012), aquatic plant restoration (Zeng et al., 2017; Liu et al., 2019), etc., but their effects on nitrification and denitrification is still limited (Lu et al., 2014). Effective nitrification requires high DO levels (e.g., >8 mg/L). At low DO levels (3 mg/L), ammonia nitrogen removal efficiency can be greatly hindered by $50 \%$ or more. Nitrobacteria generally turn to anaerobic respiration when the oxygen concentration is lower than $6.4 \mathrm{mg} / \mathrm{L}$ (Wang et al., 2015). Therefore, intermittent aeration may be needed to maintain the DO concentration between 5-6 $\mathrm{mg} / \mathrm{L}$ at the storm water outlets (III). Biological processes can be integrated to bolster nitrifying bacteria populations and two successful cases include a novel water biofilm pretreatment process with reed addition (Feng et al., 2013) and bioactive thin layer coverage that enhances in situ microbial regeneration (Zhou et al., 2016b).

\section{Conclusions}

For the Changxing River as an important inflow river into the Taihu Lake, human activities, such as the discharge of domestic sewage and agricultural sewage, have affected its microbial ecology. Thereinto, T, $\mathrm{P}$, concentrations of TP and $\mathrm{COD}_{\mathrm{Mn}}$ were the main factors that govern the overall microbial community and distribution of dominant bacteria in the algae-polluted river. The results provided a reference for the impact of pollution types on river microbial ecosystems under complex hydrological condition and a guidance for the recovery of natural water ecological function in algae-polluted rivers.

\section{Declarations}

\section{Ethics approval and consent to participate}

Not applicable.

\section{Consent for publication}

Not applicable. 
Availability of data and materials

All data generated or analysed during this study are included in this published article [and its supplementary information files].

\section{Competing interests}

The authors declare that they have no competing interests.

\section{Acknowledgements}

This work was financially supported by the Major Science and Technology Program for Water Pollution Control and Treatment (2018ZX07208009), and the National Natural Science Foundation of China (No. 51961125101).

\section{Authors' contributions}

Yajie Zhang: Conceptualization, Methodology, Formal analysis, Investigation, Data

Curation, Writing-Original Draft;

Ye Zhang: Methodology, Investigation, Data Curation, Project administration;

Lecheng Wei: Methodology, Formal analysis, Investigation, Visualization;

Mengyan Li: Methodology, Investigation, Data Curation, Visualization;

Weitang Zhu: Formal analysis, Investigation, Data Curation;

Liang Zhu: Resources, Supervision, Funding acquisition

\section{References}

1. Arnon S, Packman A, Peterson C, Gray K (2007) Effect of overlying velocity on periphyton structure and denitrification. J Geophys Res-Biogeosci 112:G01002

2. Battin TJ, Besemer K, Bengtsson MM, Romani AM, Packmann Al (2016) The ecology and biogeochemistry of stream biofilms. Nat Rev Microbiol 14(4):251-263

3. Cerco CF, Threadgill T, Noel MR, Hinz S (2013) Modeling the pH in the tidal fresh Potomac River under conditions of varying hydrology and loads. Ecol Model 257:101-112

4. Chen CY, Pan G, Shi WQ, Xu F, Techtmann SM, Pfiffner SM, Hazen TC (2018) Clay Flocculation Effect on Microbial Community Composition in Water and Sediment. Frontiers in Environmental Science 6:60-

5. Du C, Li Y, Wang Q, Liu G, Zheng Z, Mu M, Li Y (2017) Tempo-spatial dynamics of water quality and its response to river flow in estuary of Taihu Lake based on GOCl imagery. Environ Sci Pollut Res 
24(36):28079-28101

6. Feng LJ, Zhu L, Yang Q, Yang GF, Xu J, Xu XY (2013) Simultaneous enhancement of organics and nitrogen removal in drinking water biofilm pretreatment system with reed addition. Bioresour Technol 129:274-280

7. Feng Q, Han L, Tan X, Zhang Y, Meng T, Lu J, Lv J (2016) Bacterial and Archaeal Diversities in Maotai Section of the Chishui River, China. Curr Microbiol 73(6):924-929

8. Gilbert JA, Steele JA, Caporaso JG, Steinbrück L, Reeder J, Temperton B, Huse S, McHardy AC, Knight R, Joint I, Somerfield P, Fuhrman JA, Field D (2012) Defining seasonal marine microbial community dynamics. ISME J 6(2):298-308

9. Hampel JJ, McCarthy MJ, Gardner WS, Zhang L, Xu H, Zhu GW, Newell SE (2018) Nitrification and ammonium dynamics in Taihu Lake, China: seasonal competition for ammonium between nitrifiers and cyanobacteria. Biogeosciences 15(3):733-748

10. He Y, Chen Y, Zhang Y, Huang M (2012) Role of Aerated Turbulence in the Fate of Endogenous Nitrogen from Malodorous River Sediments. Environ Eng Sci 30(1):11-16

11. Jiang Z, Chen J, Zhou F, Shou L, Chen Q, Tao B, Yan X, Wang K (2015) Controlling factors of summer phytoplankton community in the Changjiang (Yangtze River) Estuary and adjacent East China Sea shelf. Cont Shelf Res 101:71-84

12. Liao K, Bai Y, Huo Y, Jian Z, Hu W, Zhao C, Qu J (2018) Integrating microbial biomass, composition and function to discern the level of anthropogenic activity in a river ecosystem. Environ Int 116:147155

13. Lilndenschmidt KE (1999) Controlling the Growth of Microcystis Using Surged Artificial Aeration. Int Rev Hydrobiol 84(3):243-254

14. Liu J, Liang XQ, Yang JJ, Ye YS, Su MM, Nie ZY, Chen YX (2011) Size distribution and composition of phosphorus in the East Tiao River, China: The significant role of colloids. J Environ Monit 13(10):2844-2850

15. Liu L, Xu ZX, Reynard NS, Hu CW, Jones RG (2013) Hydrological analysis for water level projections in Taihu Lake, China. J Flood Risk Manag 6(1):14-22

16. Liu Y, Tong TL, Li BX, Xie SG (2019) Dynamics of bacterial communities in a river water treatment wetland. Ann Microbiol 69(6):637-645

17. Lu H, Chandran K, Stensel D (2014) Microbial ecology of denitrification in biological wastewater treatment. Water Res 64:237-254

18. Lu S, Sun Y, Zhao X, Wang L, Ding A, Zhao X (2016) Sequencing Insights into Microbial Communities in the Water and Sediments of Fenghe River, China. Arch Environ Contam Toxicol 71(1):122-132

19. Lundgaard ASB, Treusch AH, Stief P, Thamdrup B, Glud RN (2017) Nitrogen cycling and bacterial community structure of sinking and aging diatom aggregates. Aquat Microb Ecol 79(2):85-99

20. Ouyang L, Chen HR, Liu XY, Wong MH, Xu FF, Yang XW, Xu W, Zeng QH, Wang WM, Li SF (2020) Characteristics of spatial and seasonal bacterial community structures in a river under 
anthropogenic disturbances. Environ Pollut 264:114818

21. Paerl HW, Gardner WS, Havens KE, Joyner AR, McCarthy MJ, Newell SE, Qin B, Scott JT (2016) Mitigating cyanobacterial harmful algal blooms in aquatic ecosystems impacted by climate change and anthropogenic nutrients. Harmful Algae 54:213-222

22. Paerl HW, Xu H, Hall NS, Zhu G, Qin B, Wu Y, Rossignol KL, Dong L, McCarthy MJ, Joyner AR (2014) Controlling Cyanobacterial Blooms in Hypertrophic Lake Taihu, China: Will Nitrogen Reductions Cause Replacement of Non- $\mathrm{N}_{2}$ Fixing by $\mathrm{N}_{2}$ Fixing Taxa? PLoS One 9(11):e113123

23. Portillo MC, Anderson SP, Fierer N (2012) Temporal variability in the diversity and composition of stream bacterioplankton communities. Environ Microbiol 14(9):2417-2428

24. Ren W, Wang P, Yan J, Liu G, Zeng B, Hussain T, Peng C, Yin J, Li T, Wei H, Zhu G, Reiter RJ, Tan B, Yin $Y$ (2018) Melatonin alleviates weanling stress in mice: Involvement of intestinal microbiota. J Pineal Res 64(2):e12448

25. Rodriguez-Mozaz S, Chamorro S, Marti E, Huerta B, Gros M, Sanchez-Melsio A, Borrego CM, Barcelo D, Balcazar JL (2015) Occurrence of antibiotics and antibiotic resistance genes in hospital and urban wastewaters and their impact on the receiving river. Water Res 69:234-242

26. Santos M, Oliveira H, Pereira JL, Pereira MJ, Gonçalves FJM, Vidal T (2019) Flow cytometry analysis of low/high DNA content (LNA/HNA) bacteria as bioindicator of water quality evaluation. Ecol Indic 103:774-781

27. Sharuddin SS, Ramli N, Mohd-Nor D, Hassan M, Maeda T, Shirai Y, Sakai K, Tashiro Y (2018) Shift of low to high nucleic acid bacteria as a potential bioindicator for the screening of anthropogenic effects in a receiving river due to palm oil mill effluent final discharge. Ecol Indic 85:79-84

28. Sun W, Xia C, Xu M, Guo J, Sun G (2017) Seasonality Affects the Diversity and Composition of Bacterioplankton Communities in Dongjiang River, a Drinking Water Source of Hong Kong. Front Microbiol 8:1644

29. Tang JY, Bu YQ, Zhang XX, Huang KL, He XW, Ye L, Shan ZJ, Ren HQ (2016) Metagenomic analysis of bacterial community composition and antibiotic resistance genes in a wastewater treatment plant and its receiving surface water. Ecotox Environ Safe 132:260-269

30. Tang XQ, Huang SL, Scholz M, Li JZ (2009) Nutrient Removal in Pilot-Scale Constructed Wetlands Treating Eutrophic River Water: Assessment of Plants, Intermittent Artificial Aeration and Polyhedron Hollow Polypropylene Balls. Water Air Soil Pollut 197(1-4):61-73

31. Unrein F, O'Farrell I, Izaguirre I, Sinistro R, dos Santos Afonso M, Tell G (2010) Phytoplankton response to $\mathrm{pH}$ rise in a $\mathrm{N}$-limited floodplain lake: relevance of $\mathrm{N}_{2}$-fixing heterocystous cyanobacteria. Aquat Sci 72(2):179-190

32. Wang FE, Tian P, Yu J, Lao GM, Shi TC (2011) Variations in pollutant fluxes of rivers surrounding Taihu Lake in Zhejiang Province in 2008. Phys Chem Earth 36(9):366-371

33. Wang L, Dong K, Geng CY, Li JR, Yu LJ, Xu C, Zhu HL (2015) Effects of do on nitrogen release and transition from sediments to water of the jialu river. Fresenius Environ Bull 24(6B):2009-2016 
34. Wang XL, Lu YL, Han JY, He GZ, Wang TY (2007) Identification of anthropogenic influences on water quality of rivers in Taihu watershed. J Environ Sci 19(4):475-481

35. Wood SA, Depree C, Brown L, McAllister T, Hawes I (2015) Entrapped Sediments as a Source of Phosphorus in Epilithic Cyanobacterial Proliferations in Low Nutrient Rivers. PLoS One 10(10):e0141063

36. Wu Z, Wang X, Chen Y, Cai Y, Deng J (2018) Assessing river water quality using water quality index in Lake Taihu Basin, China. Sci Total Environ 612:914-922

37. Yang L, Han J, Xue J, Zeng L, Shi J, Wu L, Jiang Y (2013) Nitrate source apportionment in a subtropical watershed using Bayesian model. Sci Total Environ 463-464:340-347

38. Zeglin LH (2015) Stream microbial diversity in response to environmental changes: review and synthesis of existing research. Front Microbiol 6:454-454

39. Zeng L, He F, Dai Z, Xu D, Liu B, Zhou Q, Wu Z (2017) Effect of submerged macrophyte restoration on improving aquatic ecosystem in a subtropical, shallow lake. Ecol Eng 106:578-587

40. Zhang J, Wu P, Hao B, Yu Z (2011) Heterotrophic nitrification and aerobic denitrification by the bacterium Pseudomonas stutzeri YZN-001. Bioresour Technol 102(21):9866-9869

41. Zhang M, Yu N, Chen L, Jiang C, Tao Y, Zhang T, Chen J, Xue D (2012) Structure and seasonal dynamics of bacterial communities in three urban rivers in China. Aquat Sci 74(1):113-120

42. Zhang L, Li L, Liu M, Hu Y, Jiang J (2019a) Temporal and spatial variations of bacterial community compositions in two estuaries of Chaohu Lake. J Oceanol Limnol 38:745-758

43. Zhang M, Wu Z, Sun Q, Ding Y, Ding Z, Sun L (2019b) Response of chemical properties, microbial community structure and functional genes abundance to seasonal variations and human disturbance in Nanfei River sediments. Ecotox Environ Safe 183:109601

44. Zhang W, Gu J, Li Y, Lin L, Wang P, Wang C, Qian B, Wang H, Niu L, Wang L, Zhang H, Gao Y, Zhu M, Fang S (2019c) New Insights into Sediment Transport in Interconnected River-Lake Systems Through Tracing Microorganisms. Environ. Sci. Technol., 53(8), 4099-4108

45. Zhang L, Zhao F, Li XC, Lu WX (2020) Contribution of influent rivers affected by different types of pollution to the changes of benthic microbial community structure in a large lake. Ecotox Environ Safe 198:110657

46. Zhou Y, Zhang Y, Jeppesen E, Murphy KR, Shi K, Liu M, Liu X, Zhu G (2016a) Inflow rate-driven changes in the composition and dynamics of chromophoric dissolved organic matter in a large drinking water lake. Water Res 100:211-221

47. Zhou ZM, Huang TL, Yuan BL (2016b) Nitrogen reduction using bioreactive thin-layer capping (BTC) with biozeolite: A field experiment in a eutrophic river. J Environ Sci 42:119-125

48. Zhou S, Zhang Y, Huang T, Liu Y, Fang K, Zhang C (2019) Microbial aerobic denitrification dominates nitrogen losses from reservoir ecosystem in the spring of Zhoucun reservoir. Sci Total Environ 651:998-1010 
49. Zhu C, Zhang J, Nawaz MZ, Mahboob S, Al-Ghanim KA, Khan IA (2019) Seasonal succession and spatial distribution of bacterial community structure in a eutrophic freshwater Lake, Lake Taihu. Sci Total Environ 669:29-24

\section{Figures}

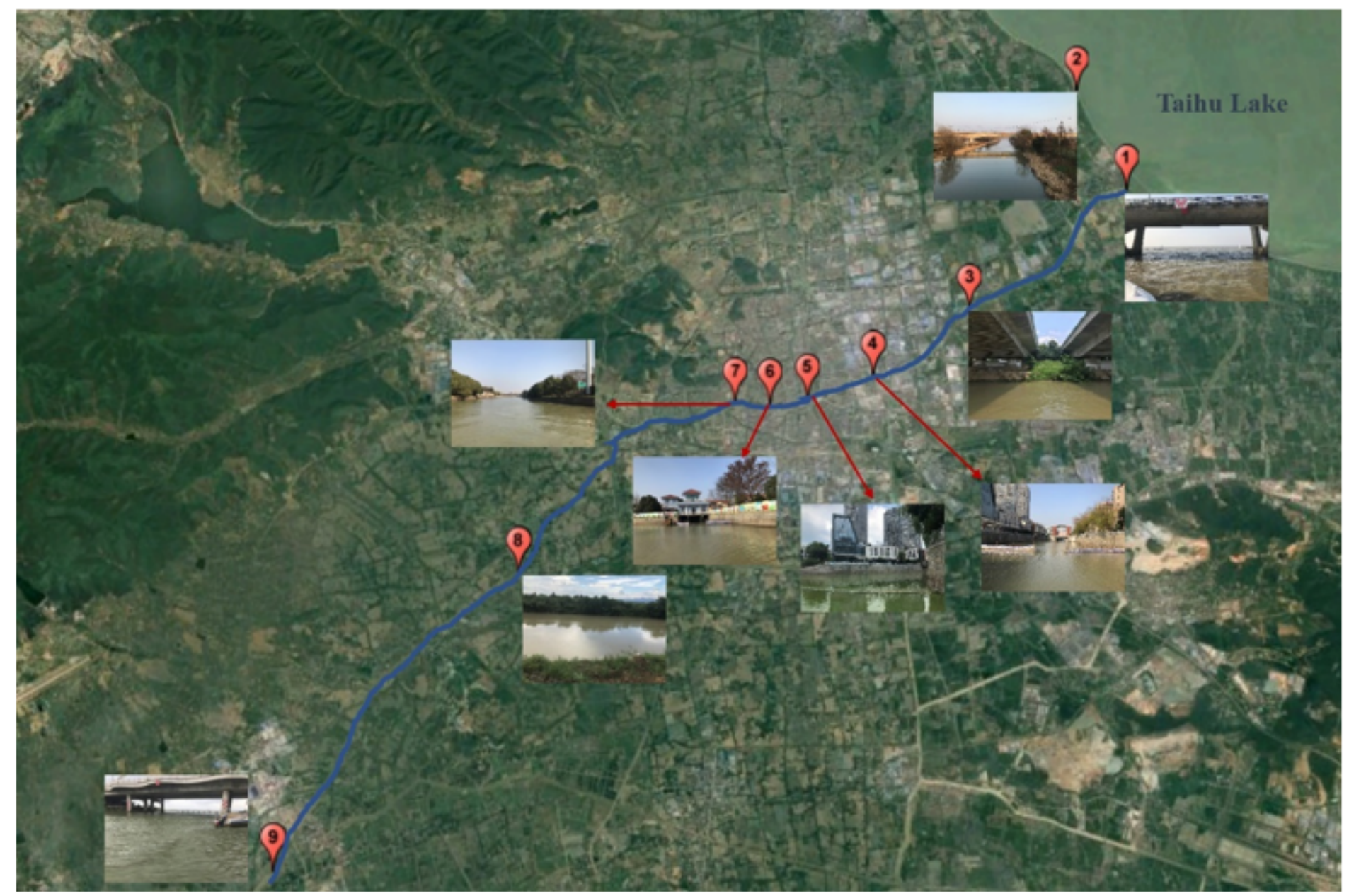

\section{Figure 1}

Locations of sampling sites along Changxing River 
(a)
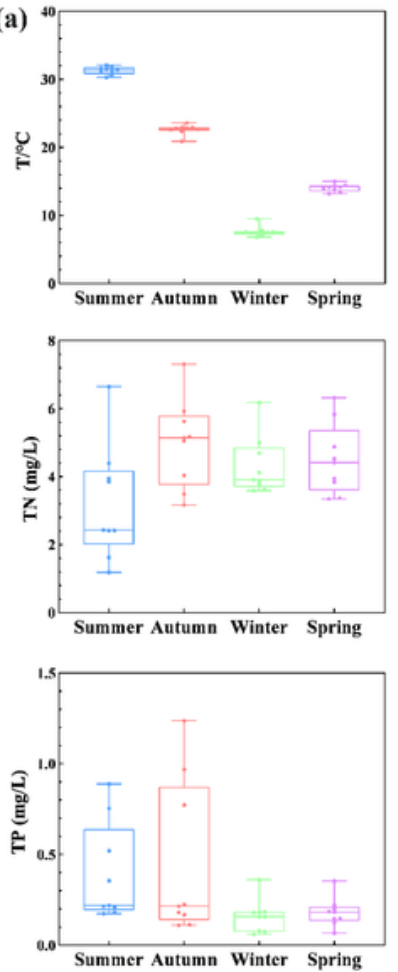

(b)
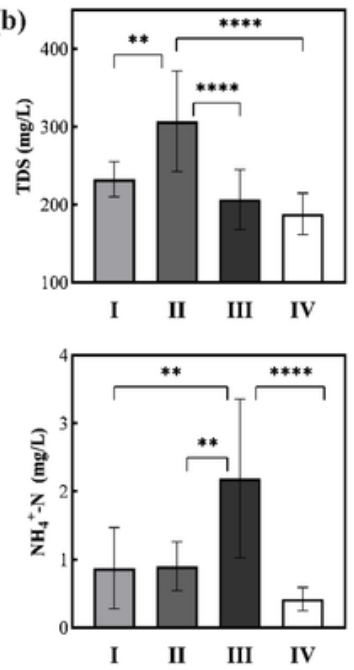

(c)

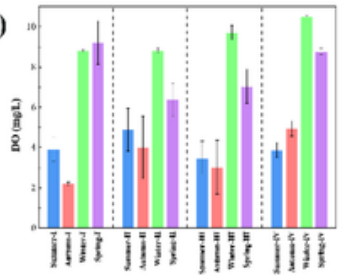

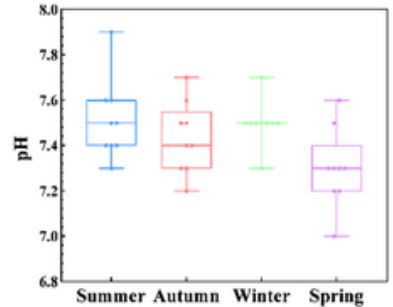
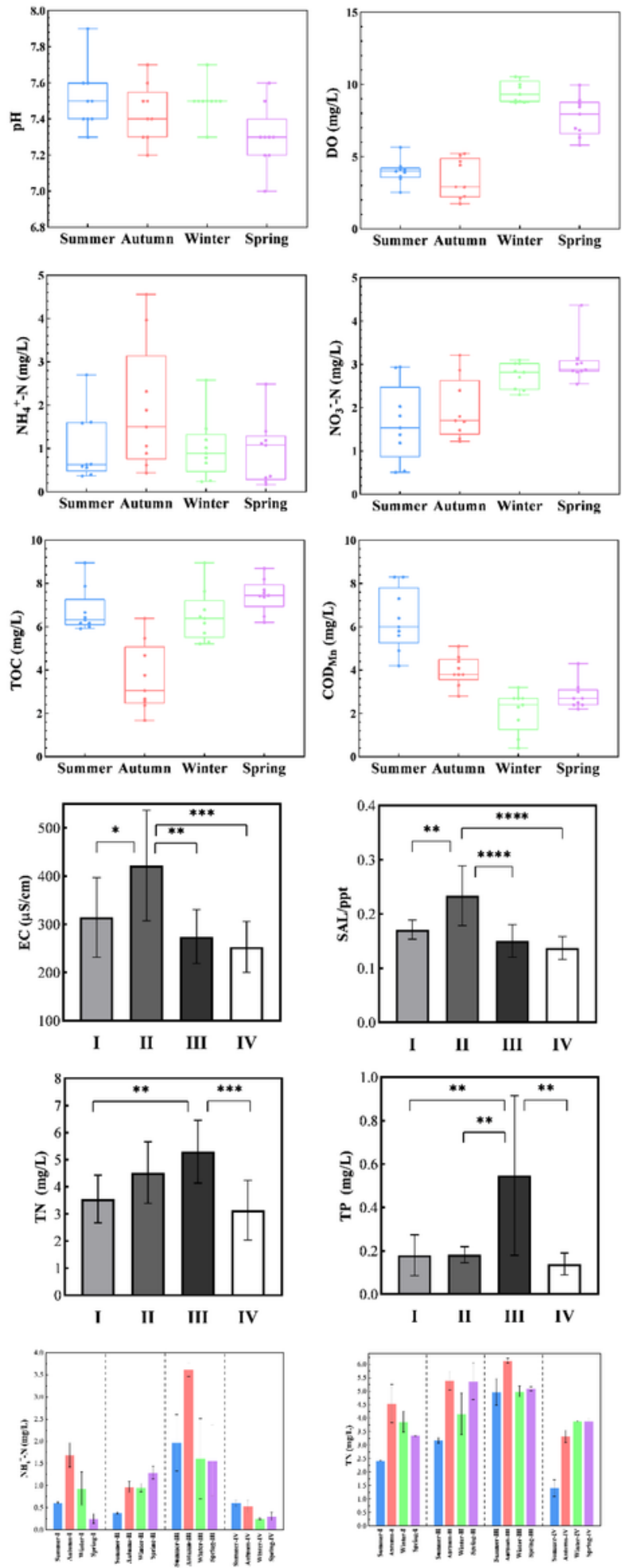

Figure 2

Physicochemical characteristics in water samples collected in Changxing River in response to (a) seasons, (b) pollution types and (c) sites (I: Estuary of Taihu Lake; II: Discharge outlets of urban wastewater treatment plants; III: Storm water outlets; IV: Non-point source agricultural drainage areas) 

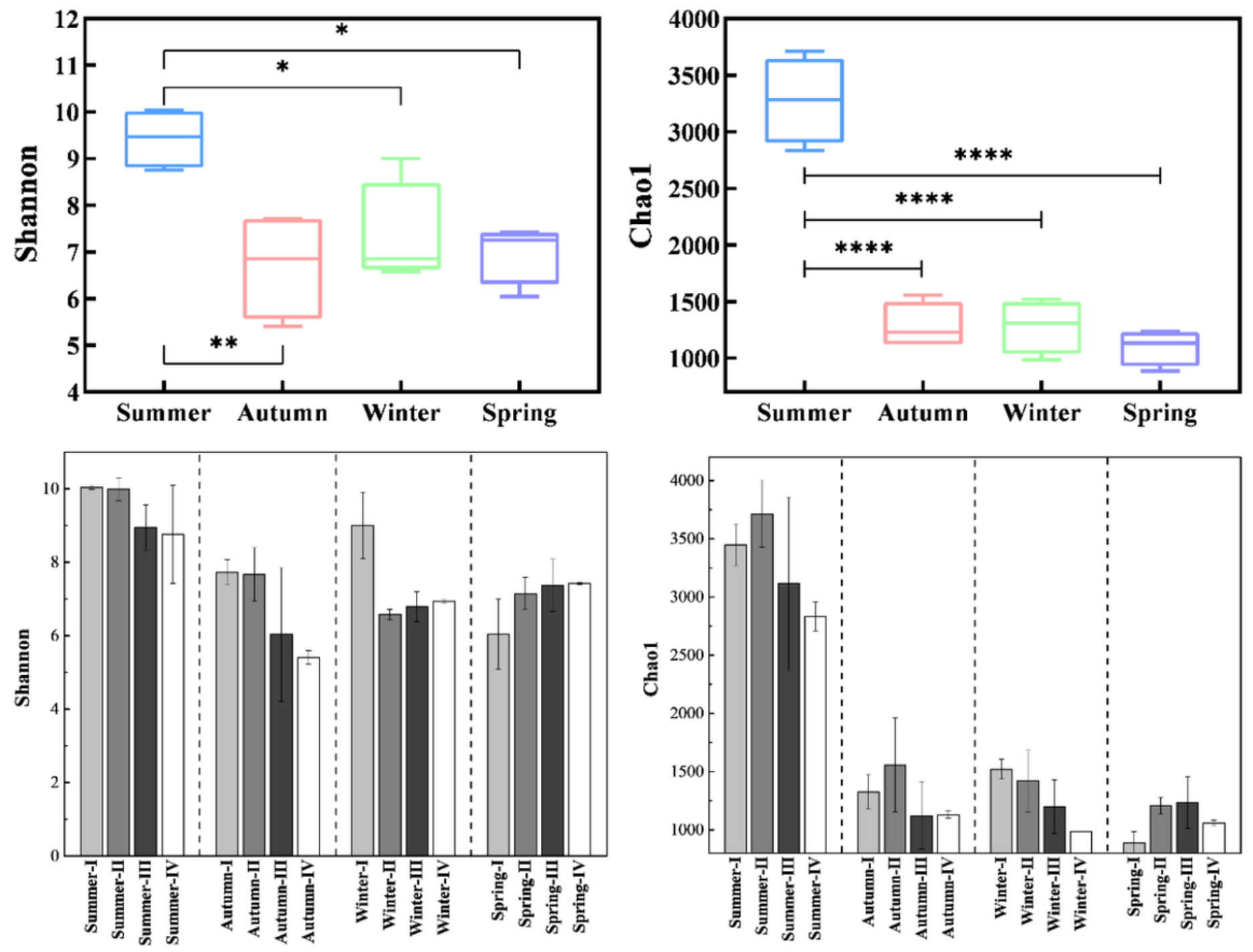

Figure 3

Alpha-diversity of microbial community in water samples collected in Changxing River (I: Estuary of Taihu Lake; II: Discharge outlets of urban wastewater treatment plants; III: Storm water outlets; IV: Non-point source agricultural drainage areas) 


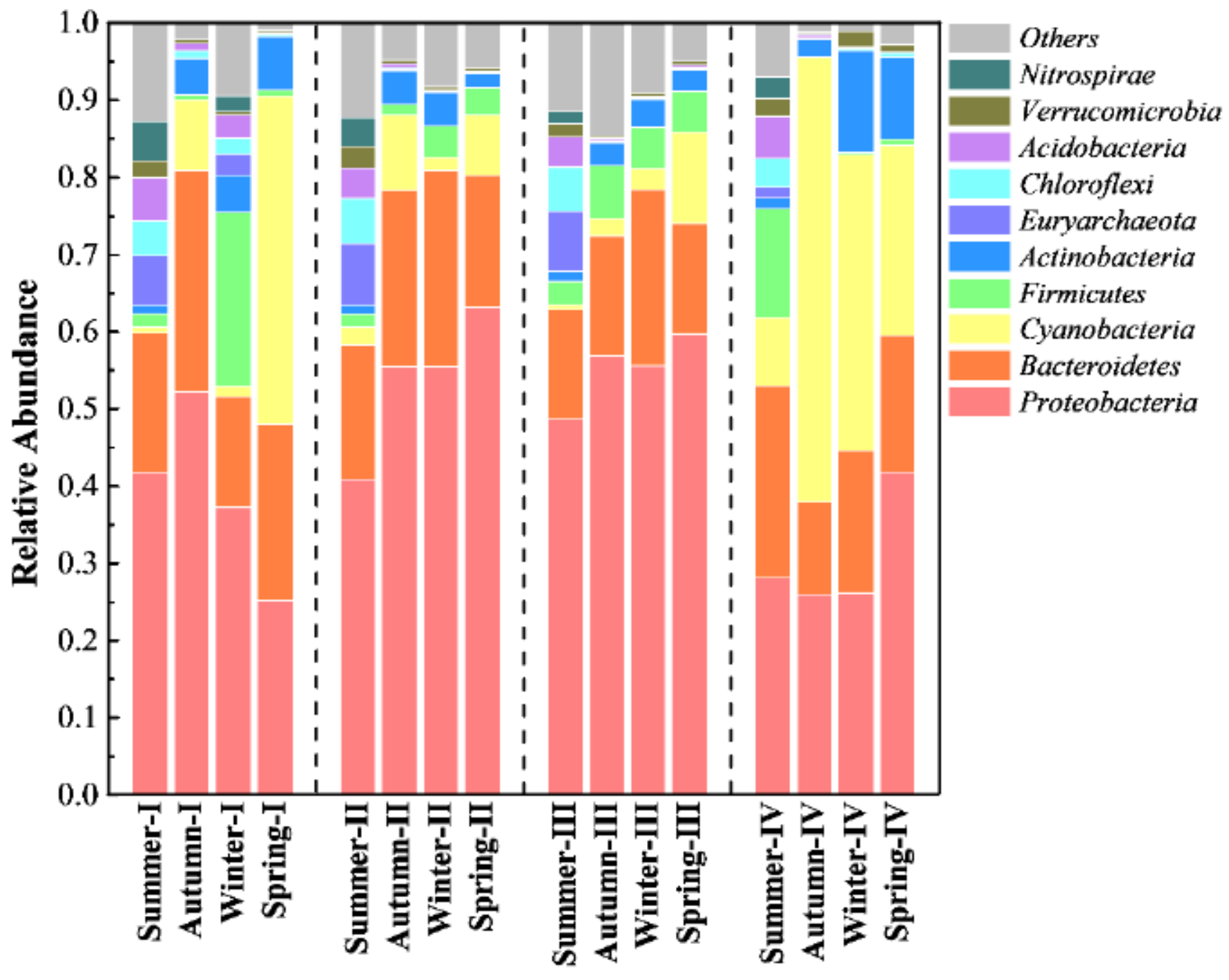

Figure 4

Microbial community compositions water samples collected in Changxing River (at phylum level) (I: Estuary of Taihu Lake; II: Discharge outlets of urban wastewater treatment plants; III: Storm water outlets; IV: Non-point source agricultural drainage areas) 


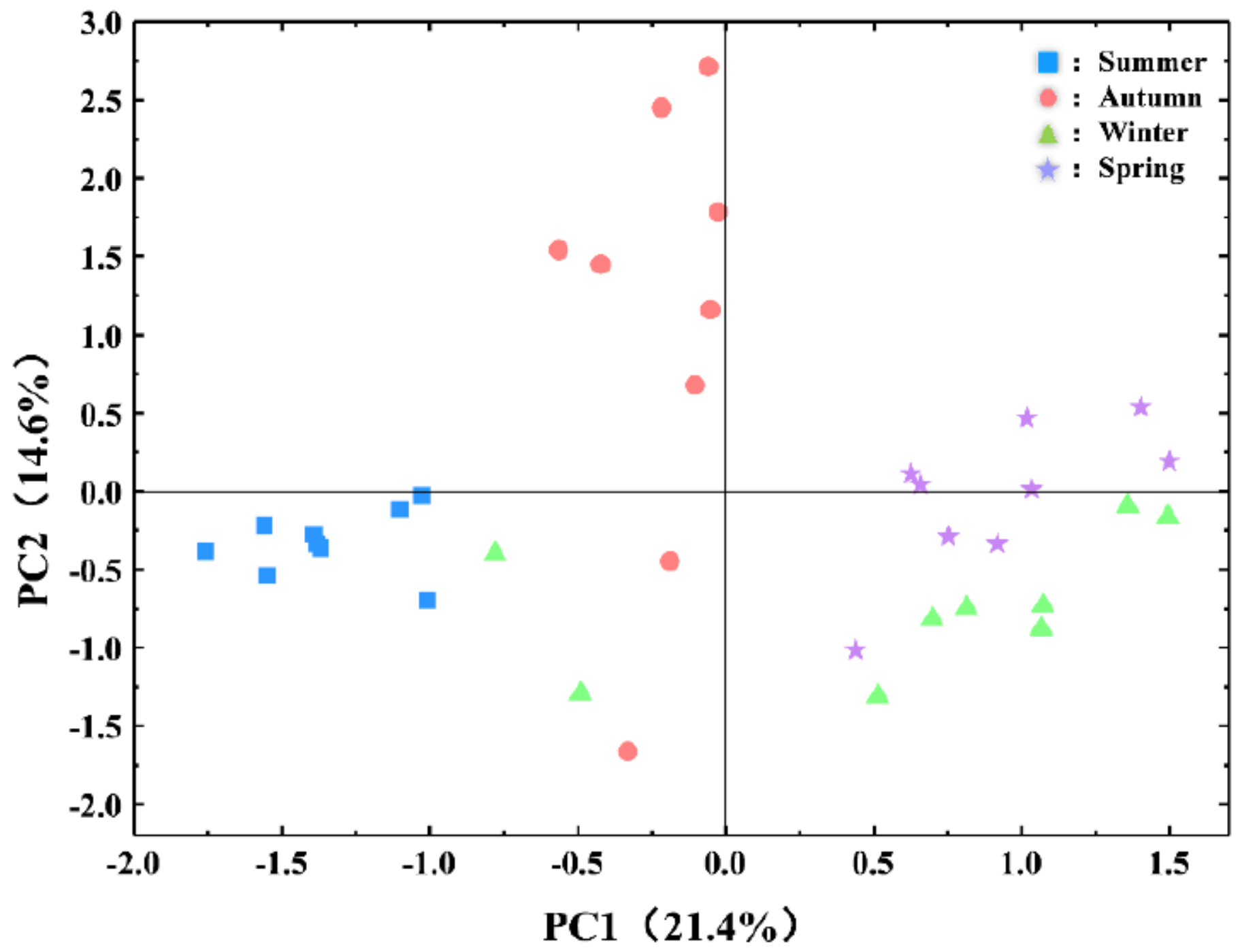

Figure 5

PCA of aquatic microbial communities in water samples collected in the Changxing River at the genus level 


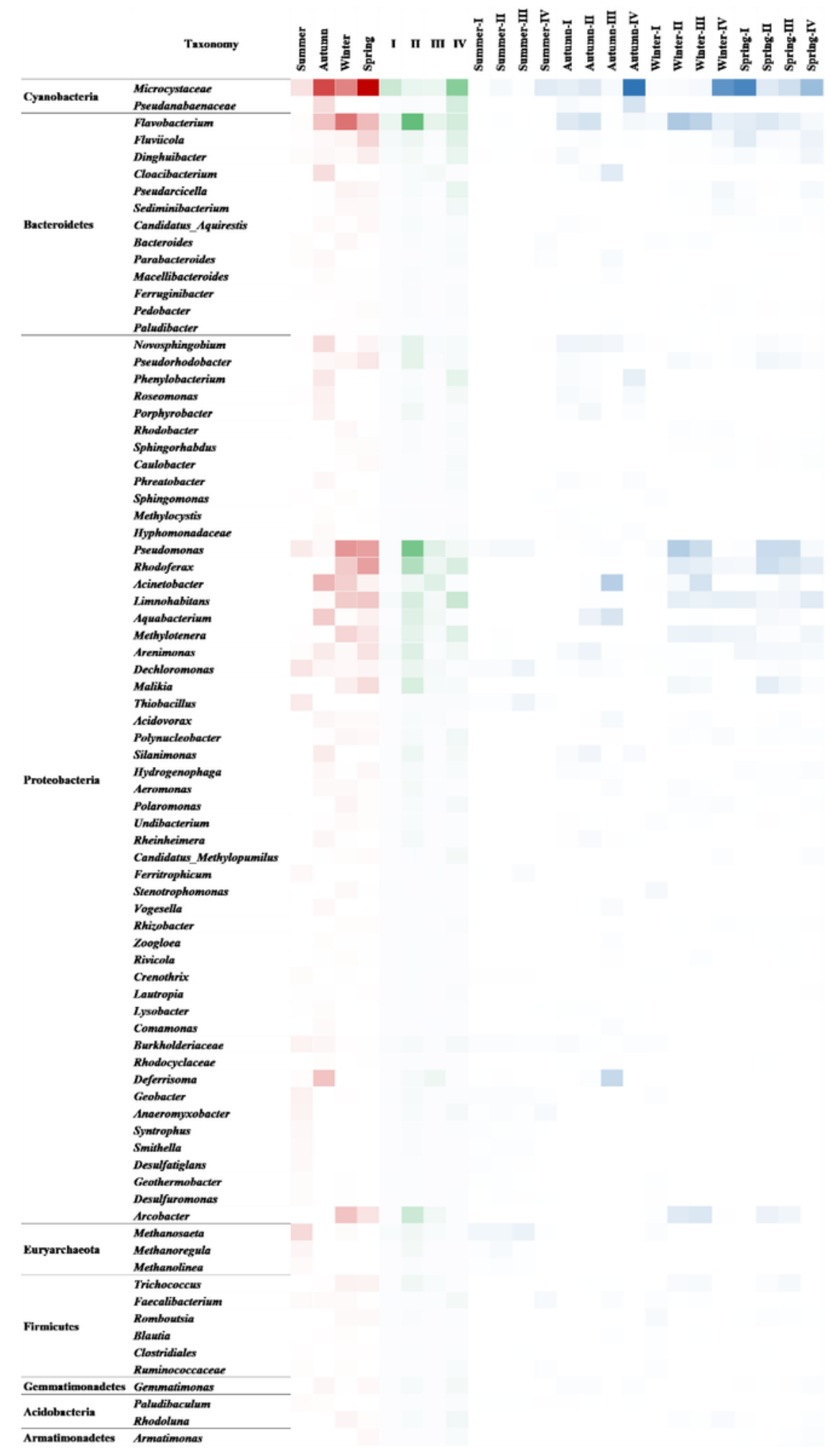

\section{Figure 6}

Relative abundance of the 80 most abundant genera in aquatic microbial populations in Changxing River 

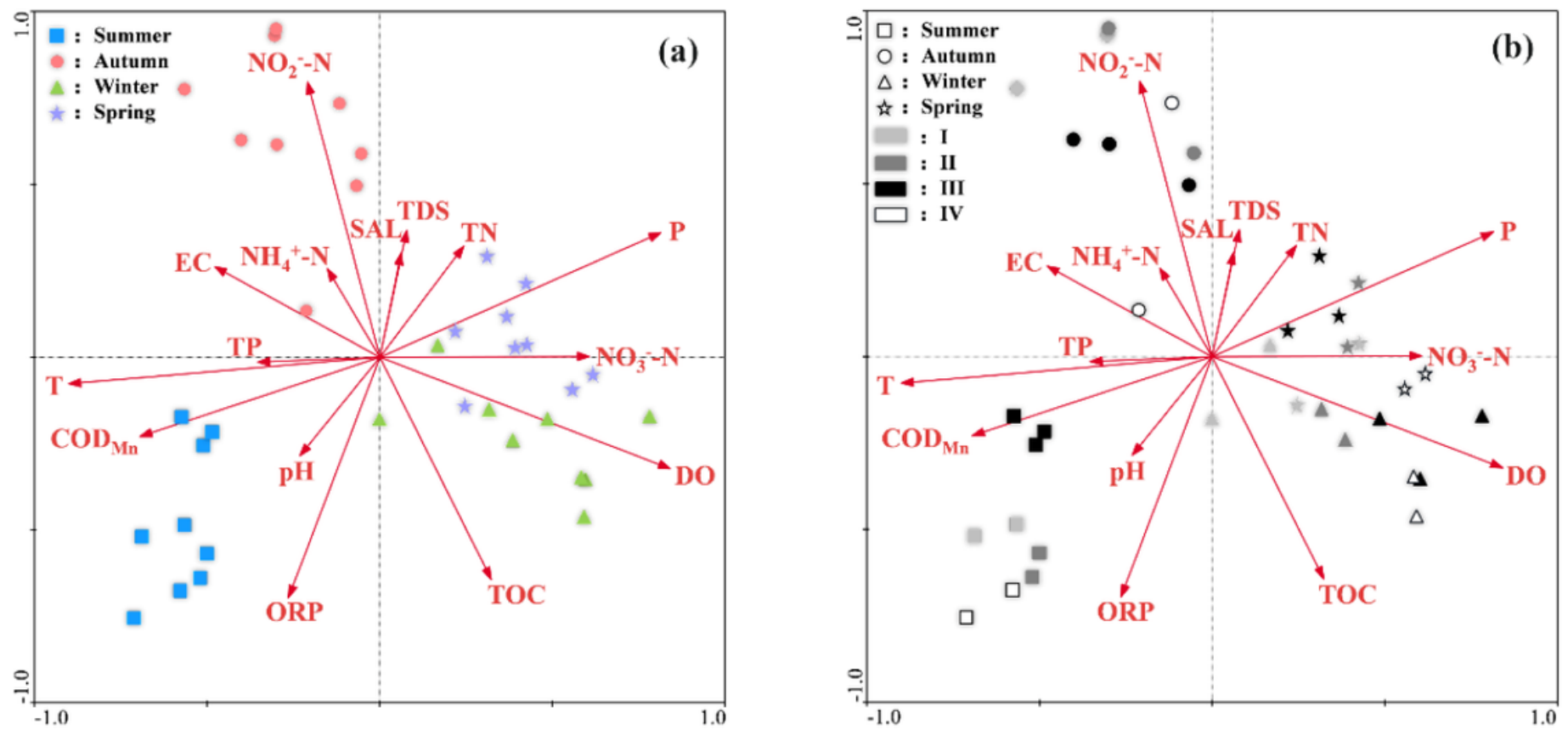

Figure 7

Redundancy analysis of dominant microorganisms and environmental variables in response to (a) seasons and (b) pollution types
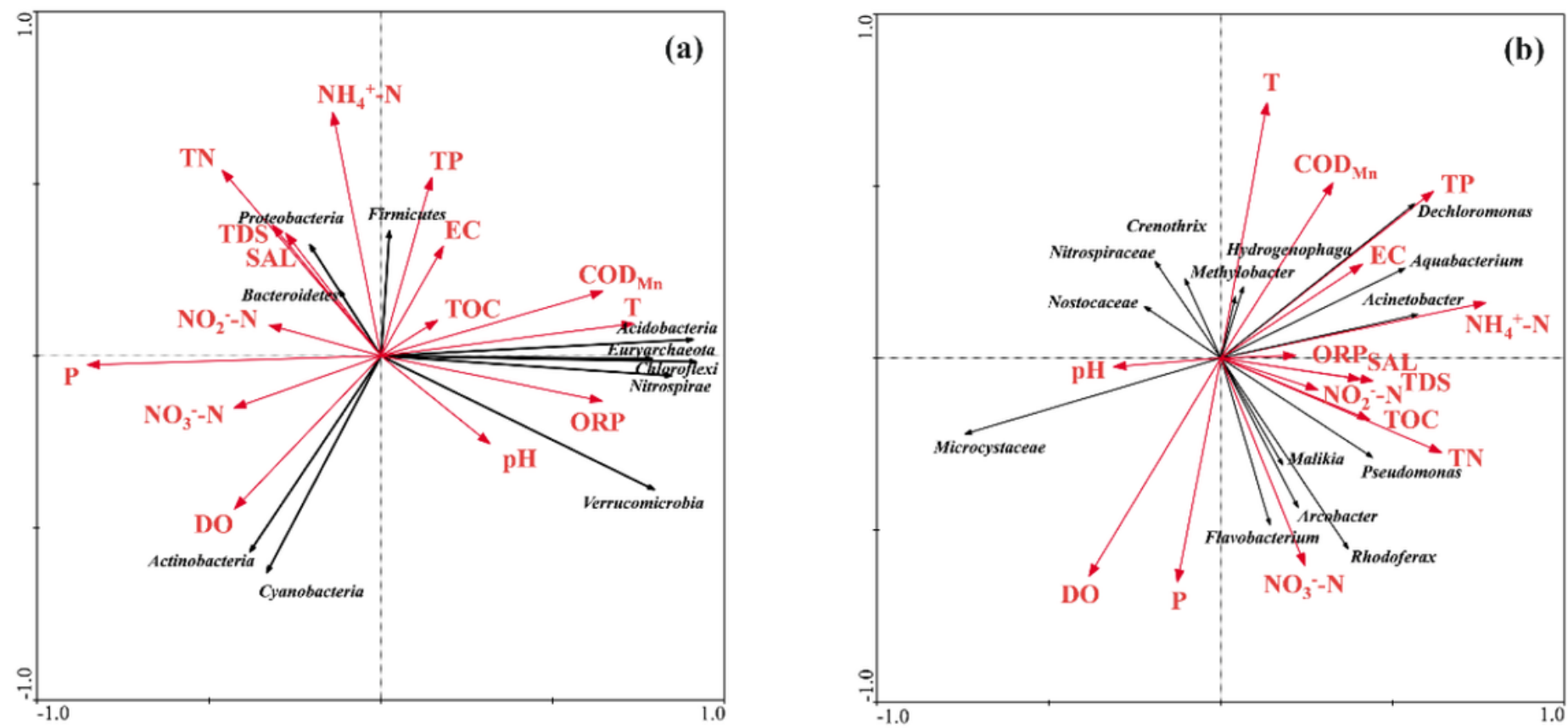

Figure 8

RDA of key species and environmental variables at the (a) phylum level and (b) the genus level 